\title{
PRIVATIZATION OF HIGHER EDUCATION IN INDIA: NEED, IMPACT AND SUGGESTIONS
}

\section{Manmeet Oberoi Baweja}

\author{
Principal Shah Satnam ji College of Education, Sirsa \\ DOI: http://dx.doi.org/10.24327/ijrsr.2017.0803.0046
}

\begin{tabular}{l} 
ARTICLE INFO \\
\hline Article History: \\
Received $17^{\text {th }}$ December, 2016 \\
Received in revised form $21^{\text {st }}$ \\
January, 2017 \\
Accepted $05^{\text {th }}$ February, 2017 \\
Published online $28^{\text {th }}$ March, 2017 \\
\hline
\end{tabular}

Key Words:

Higher Education, Privatization, Employability,

\begin{abstract}
India has world's third largest higher educational system, next to China and United States. The mission of higher education is to achieve access, equality, justice, quality, employability, inclusiveness and create a knowledge society/economy. The deteriorating administration, unproductive practice, corruption and fund unavailability leads to break down of indigenous educational system. To tackle with the problem of unavailability of funds, instead of setting up new institutions, which require huge investments, priority of the government is to expand the capacity of existing institutions and to open the new educational institutions in higher education in private sector only. There are three forms of privatization of higher education institutes- Government self financing institutes, Government aided private self financing institutes and completely private higher education institutes. The need to privatize higher education is explained in this paper. The impact of privatization in higher education is positive as well as negative. The suggestions to take maximum benefits from privatization are also discussed.
\end{abstract}

Copyright (C) Manmeet Oberoi Baweja, 2017, this is an open-access article distributed under the terms of the Creative Commons Attribution License, which permits unrestricted use, distribution and reproduction in any medium, provided the original work is properly cited.

\section{INTRODUCTION}

Education has always been considered as the only key component of human development and greatest liberating force that contributes significantly to economic development. A well developed and equitable system of higher education that promotes quality learning as consequence of both teaching and research is pivot for success in the emerging knowledge economy. The developed world understood much earlier the fact that individuals with higher education have an edge over their counterparts. They are the ones who always believed that any amount of investment in higher education was justifiable. So, it is important for developing countries like India to give due importance to both the quantitative and qualitative expansion of higher education, but the higher education system in India we inherited had been designed by a British government to suit their requirements since then no systematic efforts have been made to redesign and reorient the higher education system to meet the enormous task of economic regeneration, social transformation and political consolidation. It is not that nobody thought about modifying higher education; numerous committee reports, commission documents and national policies have made many valuable recommendations; but the higher education system remains unchanged, almost unaffected.

\section{Higher Education Scenario in India}

India's higher education system is the world's third largest in terms of students, next to China and the United States. Unlike China, however, India has the advantage of English being the primary language of higher education and research. India educates approximately 11 per cent of its youth in higher education as compared to 20 per cent in China. The main governing body at the tertiary level is the University Grants Commission (India), which enforces its standards, advises the government, and helps coordinate between the centre and the state. Universities and its constituent colleges are the main institutes of higher education in India. As of 2011, India has 43 central universities, 130 deemed universities, 275 state universities, 90 private universities, 93 institutes of national importance and about 33,000 colleges. Most of these universities in India have affiliating colleges where undergraduate courses are being taught (Gautam, Parihar \& Khare, 2015). Even after significant expansion in the postindependent period, access to higher education in India continues to be poor and more so for the disadvantaged groups. The mission of higher education is to achieve access, equality, justice, quality, employability, inclusiveness and create a knowledge society/economy. But the overall scenario of higher education in India does not match with the global Quality standards. Hence, there is enough justification for an increased assessment of the Quality of the country's educational 
institutions. Though India has a long heritage of quality higher education system it has failed to solve the problems of higher education until recent past. The deteriorating administration, unproductive practice, corruption and fund unavailability leads to break down of indigenous educational system. To tackle with the problem of unavailability of funds, instead of setting up new institutions, which require huge investments, priority of the government is to expand the capacity of existing institutions. This also infers that new education institutions in higher education would only be opened in private sector. None can deny the importance of private sector especially in tertiary education given the magnitude of challenge. But, government abdicating its responsibility for this crucial sector is fraught with grave implications. Public sector versus private sector accounts for about 62 per cent of the total enrolment in higher education in India. The massive privatization of higher education would deprive a large section of Indians from the ambit of higher education.

\section{Privatization}

Privatization means initiation of private ownership, management and control of organizations. The control is in terms of decision making and responsibility of money and administration. In education privatization can be seen as expansion of private sector's control. Providing education to one and all has been one of the primary duties of the government. But there is a wave of privatization of education in our country. Actually government has diverted its focus from higher education to primary education and urged private sector to enter this sector which is termed as privatization of higher education's economic reforms were introduced in Indiain1991.

Privatization of higher education has emerged in several forms in the recent decade. Privatization within government higher education institutions takes place in the form of introducing self-financing courses within government institutions. Second form is converting government aided private institution in to private self financing institution. Third form of privatization is allowing self financing private institution with recognition and also without recognition. This may be termed as commercial private higher education institutions. Private Institutes are mainly allowed to set up state private universities, deemed university and academic institution with foreign collaboration. Kapur and Mehta (2006) described the evolution of privatization in Indian higher education using a phrase, "from half-baked socialism to half bake capitalism." They argued that much of the massive privatization has not resulted from ideological commitments of key actors but is instead a result of collapse of the state system resulting in weak ideological and institutional foundations.

\section{Need of Privatization in Higher Education}

The need to privatize higher education is because of following reasons:

1. To increase competitive efficiency of public sector.

2. To meet the growing demand of higher education with rapid growth in population.

3. To reduce financial burden on government and for decentralization of educational institutions.
4. For imparting quality education and training and shaping of the curriculum according to global, national and local needs.

5. To fulfill the need for skilled manpower and to fulfill the need of the country in liberalization, privatization, and globalization.

6. To facilitate technological developments and information based economic development (Jonaki \& Prasenjit, 2016)

\section{Impact of Privatization on Higher Education}

Higher education in India has expanded rapidly over the past two decades. This growth has been mainly driven by private sector initiatives. There are genuine concerns about many of them being sub standard and exploitative. Due to the government's ambivalence on the role of private sector in higher education, the growth has been chaotic and unplanned. The regulatory system has failed to maintain standards or check exploitation. The private institutions of present are motivated by profit. The large growths of these institutions (which make huge profits) represent commercialization of education. These institutions do not hesitate to admit students with poor academic credentials. The contributions of private sector to research and advanced level education are also found to be limited. (Tilak, 2005). It is rightly observed, "higher education is far too expensive to be made privately profitable unless it is reserved for the rich or is of very poor quality" (Patel, 2003).

Trends show that of the various forms of institutes of higher education that exists, the number supported by public funding have stagnated by growth (like the central and state universities, aided colleges, etc.) and rather the numbers with private funding have witnessed a speedily rising growth (like the private universities, deemed universities, unaided colleges, etc.) (Agarwal, 2006). Within a small duration of five years from 2001-2006 the unaided private higher education accounted for 63 per cent (from 43 per cent in 2001) of the total higher education institutes and 52 per cent (from $33 \%$ in 2001) of the total higher education enrolments (FICCI, 2011). Since 2005-2011, the State Private Universities have witnessed a fifteen-fold rise in the number of institutes from 6 to 94 . Of the 130 Deemed Universities, 73 are in the private sector. About 1 per cent of colleges have been granted an autonomous status (FICCI, 2011). Quiet obviously most of this growth of private higher education has happened in the more marketable professional courses like engineering, medicine, management, computer applications, etc. ranging between 50 per cent to 95 per cent of the private institutions. (Joshi \& Ahir, 2013)

There is a number of private training institutions in our country in which students get enrolled after graduation or post graduation. After passing out B. Ed / M. Ed, they are eligible for getting jobs. In this way, these private training colleges of nursing, pharmacy, education, engineering, management, medical and law give students a way to go ahead in their lives and get better life. To the number of students in the private technical colleges, a number of students get the diploma or degrees in their respective stream like Diploma Electrical/ Mechanical/ Computer Science and Engineering. It is regulated by AICTE. India with 1200 approximate engineering Institution, 2 Lac teachers has a tremendous potential to 
become global distinction for technical education particularly for students from developing nation (Abrol, 2016).

\section{Suggestions}

The massive privatization of higher education would deprive a large section of Indians from the ambit of higher education because they are too expensive. But, experience of deemed universities that turned to be teaching shops suggest that these caveats in policy do not stand during the implementation, so it is important to ensure that these institutes have adequate faculty, research facilities, relevant curriculum and adequate infrastructure among others as per Government norms. If we can impart high quality education to them we can reap the dividend. Otherwise, it would lead to demographic nightmare. So, we should follow the best practices in accreditation and assessment. Currently only a handful of private institutions in India are accredited by NAAC and NBA (Times of India, 21st July, 2014).

In most of the institutions, there is no freedom for innovation in teaching as the private institutes have their own set rules and methods which teachers have to follow. Many a times faculty has to obey the instructions of the management where most of the members are not qualified. In these kinds of situations, privatization has provided them job opportunities but not job satisfaction. It can be achieved only if the management takes them into account.

Due to Government's policy of preferring quantity over quality, private colleges are growing daily. We can see many colleges in one area. To minimize the wastage and stagnation, Government should check private bodies seriously. Otherwise future of our children will be dark.

There is also a fact that if a private sector educational institute cannot at least recover its costs, it would be closed down. So the private institutions must be allowed to be commercial i.e. they must be allowed to break-even or make a small fair profit. If they are allowed to do so transparently, there would be no need to disguise their profit and the institute will not compromise with quality.

\section{CONCLUSION}

The private initiative in education, especially higher education is not new to India. Some of the leading universities like Banaras Hindu University and Aligarh Muslim University came up with the efforts, dedication and financial support of community and since 1990 's; trend towards privatization has been on a large scale. Government cannot absolve its responsibility of regulating private institutes. So, some regulating agencies have to be formed which assure quality and transparency and prevent profiteering in private educational institutes. There is an emergence need to regulate quality but not growth of supply.
Privatization of education has the potential to improve the quality of education as well as to reduce the cost.

To ensure access to higher education by weaker section of society, government has to increase public expenditure on higher education. On the whole, an improvement in the standards of education could be achieved through a balanced relationship between public and private sector. Although there are many drawbacks of privatization of higher education but it has the positive point that education is accessible to all, even to the rural students now a days. In fact, privatization increases of number of degrees holders on one hand and unemployment on the other hand.

\section{References}

1. Agarwal, P. (2006). "Higher Education in India: The Need for Change." ICRIER Working Paper, Indian Council for Research on International Economic Relations: No. 180.

2. FICCI. (2011). "Private sector participation in Indian higher education," FICCI higher education summit 2011, Ernst \& Young Pvt. Ltd., Kolkata.

3. Gautam, R.; Parihar, A.S.; Khare, S. (2015).”Analysis of Globalization/ Privatization of Higher Education in India, International Journal of Science, Technology and Management, Volume 4, Issue No. 1, pp 726-733.

4. Jonaki, B.; Prasenjit, P. (2016)."Higher Education in India: Recent Issues and Trends", Research Journal of Educational Sciences, Volume 4(1), 10-16.

5. Joshi, K.M.; Ahir, K.V. (2013). "Indian Higher Education: Some Reflections", Intellectual Economics, Volume 7, No. 1(15), p 42-53.

6. Kapur, D.; Mehta, P.B. (2004). Indian Higher Education Reform: From Half-Baked socialism to Half-Baked Capitalism. Harvard University: CID Working Paper No. 108. September2004.

7. Patel, I.G. (2003). Higher Education and Economic Development in JBG Tilak (ed), Education, Society and Development: National and International Perspectives, APH for NIEPA, New Delhi.

8. Tilak, Jandhyala BG (2005). Private Higher Education: Philanthropy to Profits' in Higher Education in World 2006: The Financing of Universities, GUNI Series on the Social Commitment of Universities, Palgrave, New York and GUNI.

9. Times of India, 21 $1^{\text {st }}$ July, 2014, Article "Higher Education in India: An Introspection" WikipediaHigher Education in India online https://en.m.wiki pedia.org > wiki> Highe

\section{How to cite this article:}

Manmeet Oberoi Baweja.2017, Privatization of Higher Education In India: Need, Impact And Suggestions. Int J Recent Sci Res. 8(3), pp. 15973-15975. 